\title{
Képzés és tanulmányi szerződés a rendvédelmi szerveknél
}

\section{HARGITAI Veronika ${ }^{1}$}

\begin{abstract}
A szerző a jelen tanulmányában a rendészeti szervek tagjai számára rendelkezésre álló képzési formákat mutatja be. Ismerteti a tanulmányi szerződés legfontosabb jellegzetességeit, a képzési formák föbb típusait, az egyes képzéstípusokhoz kapcsolódó jogokat és kötelezettségeket. Rámutat a képzéssel kapcsolatos problémákra és az állomány tagja által vállalt képzés nem teljesítésének vagy nem megfelelö teljesitésének jogkövetkezményeire.
\end{abstract}

Kulcsszavak: tanulmányi szerződés, megtérítési kötelezettség, továbbképzés, munkaidő-kedvezmény, képzésre kötelezés

\section{Bevezetö}

A 2015. évi XLII. törvény a rendvédelmi feladatokat ellátó szervek hivatásos állományának szolgálati jogviszonyáról (Hszt.) által biztosított rendelkezések alapján a rendvédelmi szerv tagjának továbbképzésére a hatályos szabályozás szerint több lehetőség is van.

A kötelezettségeket, a támogatásokat és a szankciók jellemzőit tekintve a képzések között azonban jelentős eltérés tapasztalható.

A hivatásos állomány tagjának szempontjából azonban egyáltalán nem mindegy, hogy a képzésre vállalkozó személy melyik képzési formát veheti vagy veszi igénybe.

A köznyelv a tanulmányi szerződést gyűjtőfogalomként használja. Így nevezik az ösztöndíjszerződéseket, a munkáltató általi jogszabályon alapuló kötelezést, és ezt a fogalmat használják a tényleges tanulmányi szerződés esetén is.

A tanulmányi szerződés sajátossága, hogy maga a szerződés, bár a munkajog területére tartozik, lényegét tekintve civiljogi, polgári jogi kategória.

A tanulmányi szerződés létjogosultságát az adja, hogy előnyös a munkáltató számára: a dolgozói továbbképzés intézményesített eszköze, és egyben a munkaerő-szükséglet biztosításának módja. A képzésért cserébe a munkáltató meghatározott ideig bizton számíthat a dolgozó munkájára. A tanulmányi szerződés ugyanakkor quasi jutal-

\footnotetext{
Dr. HARGITAI Veronika mesteroktató, Nemzeti Közszolgálati Egyetem Rendészettudományi Kar Közjogi és Rendészeti Jogi Tanszék

Veronika HARGITAI, master instructor University of Public Service Faculty of Law Enforcement, Department of Public Law and Law Enforcement Legislation https://orcid.org/0000-0001-5419-0995; hargitai.vera@uni-nke.hu

2 2015. évi XLII. törvény a rendvédelmi feladatokat ellátó szervek hivatásos állományának szolgálati jogviszonyáról.
} 
mazási eszköz is, mert ha a munkáltató tanulmányi szerződést köt a dolgozóval, ezzel egyben a dolgozójának arra érdemességét is elismeri, és a dolgozója munkáját méltányolja. A tanulmányi szerződés ugyanakkor a munkavállaló számára is előnyökkel jár, hiszen a saját képzéséhez anyagi támogatást és/vagy munkaidő-kedvezményt kap.

A munka törvénykönyvében ${ }^{3}$ meghatározott tanulmányi szerződés fogalom adja az alapját a munkáltatók és a munkavállalók között a munkavállaló képzése érdekében kötött minden megállapodásnak.

A tanulmányi szerződésben a munkáltató vállalja, hogy a tanulmányok alatt támogatást nyújt, a munkavállaló pedig arra kötelezi magát, hogy a megállapodás szerinti tanulmányokat folytatja, és a képzettség megszerzése után a támogatás mértékével arányos időn - de legfeljebb öt éven - keresztül munkaviszonyát felmondással nem szünteti meg. ${ }^{4}$

A tanulmányi szerződés mint civiljogi jogintézmény, kétoldalú megállapodás. Nem tartalmaz közhatalmi jellemzőt, esetleges megszegésének jogkövetkezményei is a civil jog keretein belül maradnak. A tanulmányi szerződés megszegése, a szerződésben foglaltak nem teljesítése esetén a szankció a támogatás visszatérítése, és nem kerül sor munkajogi jogkövetkezményekre. A felmondás, a szerződéstől mentesülés jogi szabályozása, a kötbér alkalmazhatóságának lehetősége is a tanulmányi szerződés polgári jogi jellegét igazolja. ${ }^{5}$

A rendvédelmi szerveknél a tanulmányi szerződés jogi jellegét tovább árnyalja a szolgálati viszony miatt a Hszt. és a miniszteri szintű szabályozás hatása.

A Hszt. által biztosított rendelkezések alapján a rendvédelmi szerv tagjának továbbképzésére több lehetőség is van. A kötelezettségeket, támogatásokat és a szankciók jellemzőit tekintve a képzések között azonban jelentôs eltérés tapasztalható.

A hivatásos állomány tagjának szempontjából a kötelezettségek és következmények egyáltalán nem mindegy, hogy melyik képzési formát veheti vagy veszi igénybe.

A hatályos jogszabályi rendelkezések szerint saját elhatározáson alapuló képzésben való részvételre tanulmányi szerződés alapján vagy önkéntes elhatározással az illetékes parancsnoknak való bejelentés után van lehetőség.

A hivatásos állomány tagja ugyanakkor a magasabb szolgálati beosztáshoz szükséges képzettség megszerzése érdekében mind rendvédelmi, mind polgári oktatási intézményben folytathat tanulmányokat. ${ }^{6}$

Ki kell azonban emelni, ha a hivatásos állomány tagjának képzésére a rendvédelmi szerv kötelezése alapján kerül sor, úgy az előírt kedvezményeket és a tanulmányok folytatásának valamennyi költségét az érintettel kötött megállapodás alapján a rendvédelmi szervnek kell biztosítani.

\footnotetext{
2012. évi I. törvény a munka törvénykönyvéről (Mt.).

Mt. 229. § (1) bek.

Mt. 229. § (5)-(8) bek.

31/2015. (VI. 16.) BM rendelet a belügyminiszter irányítása alá tartozó rendvédelmi feladatokat ellátó szervek hivatásos állományát érintő személyügyi igazgatás rendjéről 70 §. (1) bek.
} 
Ez a megállapodás, bár tanulmányok elvégzésére vonatkozó megállapodás, de nem minősül tanulmányi szerződésnek. ${ }^{7}$ E rendelkezés pedig teljes mértékig összhangban áll az Mt. és Hszt. azon rendelkezéseivel is, amely szerint nem köthető tanulmányi szerződés, ha a tanulmányok elvégzésére a munkáltató kötelezte a munkavállalót.

A tanulmányi szerződésnek nem minősülő, de képzésre kötelező megállapodásnak is tartalmaznia kell azonban mindazon feltételeket, amelyek egy klasszikus tanulmányi szerződés részét képeznék. Így különösen a képzőintézmény megnevezését, a képzés megnevezését és helyét, a képzési formát, a képzés jellegét és költségét, a képzés kezdő és záró időpontját, és a tanulmányi támogatás formáját és mértékét. ${ }^{8}$ Jelentős különbség van azonban a két jogintézmény között a támogatás formájában és a megállapodás megszegése esetén a jogkövetkezmények alkalmazásában.

A képzésre történő kötelezés esetén - bár anyagi értelemben nagyon előnyös a dolgozónak, hiszen a képzés minden költségét (tandíj, étkezés, utazás stb.) jogszabály által meghatározott keretek között a szolgálati hely viseli, ugyanakkor veszélyekkel is jár. A képzés nem teljesítése esetén a szankciók - miután ez esetben nem polgári jogi szerződésről van szó - nem maradnak a civil jog keretei között. Így a megállapodás nem teljesítése legrosszabb esetben akár a képzésben részt vevő személy szolgálati viszonyát is érinthetik.

A szolgálati törvény ${ }^{9}$ - a munka törvénykönyvének szabályaival összhangban - a tanulmányi szerződésre vonatkozóan tételes rendelkezést tartalmaz.

Szolgálati érdekből a munkáltatói jogkört gyakorló elöljáró a hivatásos állomány tagjával vagy a hivatásos szolgálatot vállaló személlyel tanulmányi szerződést köthet a betöltött vagy tervezett szolgálati beosztás vagy a szolgálati viszony létesítéséhez vagy fenntartásához szükséges iskolai végzettség, szakképzettség vagy rendvédelmi tárgyú szakmai képzettség iskolarendszerű vagy felnőttképzés keretében történő megszerzésére. ${ }^{10}$

Tanulmányi szerződés megkötése tehát nem kötelező, a munkáltatói jogkört gyakorló elöljáró mérlegelési jogkörébe tartozik.

Nem köthető tanulmányi szerződés, ha a tanulmányok elvégzésére a munkáltatói jogkört gyakorló elöljáró a hivatásos állomány tagját kötelezte. ${ }^{11}$

A tanulmányi szerződést (akárcsak a munkáltatói kötelezést) a lényeges tartalmi elemek: a képzés tárgya, időtartama, helye, teljesítés módja, határideje, költségek viselése, kötelezettségek rögzítésével írásba kell foglalni. ${ }^{12}$

A tanulmányi szerződésben meg kell határozni a hivatásos állomány tagját vagy a hivatásos szolgálatot vállalót megillető támogatás formáját és mértékét, a tanulmányok befejezése után a rendvédelmi szervnél kötelezően szolgálati viszonyban eltöl-

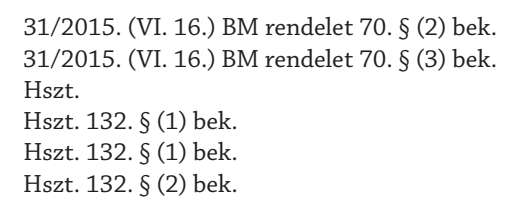


tendő idő tartamát, továbbá a tanulmányi támogatás pénzben kiszámított összegére vonatkozó megtérítési kötelezettséget, ha a hivatásos állomány tagja a tanulmányait nem fejezi be, vagy a szerződésben vállalt időtartamot önhibából nem tölti le. ${ }^{13}$

A hivatásos állomány tagja nemcsak szolgálati érdekből, hanem egyéni érdekből, magán cél érdekében is részt vehet képzésben.

A hivatásos állomány tagja azonban saját elhatározása alapján iskolarendszerú oktatásban, képzésben csak az állományilletékes parancsnoknak tett előzetes bejelentés vagy tanulmányi szerződés alapján folytathat tanulmányokat. ${ }^{14}$

A hivatásos állomány tagjának formailag a képzésben való részvételhez tehát nem engedélyt kell kérnie, csak bejelentési kötelezettsége van.

A törvény azon rendelkezése azonban, amely szerint „az állományilletékes parancsnok csak abban az esetben korlátozhatja az oktatásban, képzésben való részvételt, ha az a szolgálati érdek aránytalan sérelmével járna" - véleményem szerint - lényegében burkolt engedélyeztetési kötelezettséget jelent.

A szolgálati érdek aránytalan sérelme meghatározatlan fogalom, és mint ilyen, mindig „az eset összes körülményei” alapján ítélendő meg. A szolgálatszervezés feladatainak objektív feltételei mellett a kérdés megítélése szubjektív szempontú megközelítésre is lehetőséget ad. Az, hogy a szolgálatszervezési feladat aránytalan sérelmével jár-e a képzésen való részvétel, nagymértékben függhet az állományilletékes parancsnok személyétől, emberi hozzáállásától és a bejelentést benyújtó személy parancsnokának szubjektív megítélésétől is.

Abban az esetben azonban, ha a szolgálatszervezési érdek nem képez akadályt, és a képzésben részt vevő személy „átmegy a szubjektív szűrőn” is, akkor, bár tanulmányi szerződéssel nem rendelkezik, és így költségtérítést ugyan nem kap, de tanulmányi munkaidő-kedvezményként a tanulmányok folytatásához szükséges szabadidőt a parancsnoknak jogszabály alapján biztosítani kell számára. ${ }^{15}$ Ez esetben a képzésben való részvételhez a hivatásos állomány tagjának kérelmére illetményfolyósítás nélküli szolgálatmentességet kell biztosítani.

A szabadidő mértékét az oktatási intézmény által kiadott, a kötelező iskolai foglalkozás és szakmai gyakorlat időtartamáról szóló igazolás alapján kell megállapítani, valamint ezen túl vizsgánként, ha pedig egy vizsganapon több vizsgatárgyból kell vizsgázni, vizsgatárgyanként - a vizsga napját is beleszámítva - négy munkanap szabadidőt kell biztosítani. Vizsgának ez esetben az oktatási intézmény által meghatározott számonkérés minősül. A diplomamunka, szak- és évfolyamdolgozat elkészítéséhez mindemellett tíz munkanap szabadidőt kell biztosítani. ${ }^{16}$

\footnotetext{
Hszt. 132. § (3) bek.

Hszt. 153. § (1) bek.

Hszt. 153. § (2) bek.

Hszt. 153. § (3)-(4) bek.
} 
A tanulmányokat folytató személyt védő jogszabályi rendelkezés, hogy a szabadidőt a hivatásos állomány oktatásban, képzésben részt vevő tagja kérésének megfelelően, a tanulmányi év folyamán kell kiadni. ${ }^{17}$

A hivatásos állomány iskolarendszeren kívüli oktatásban, képzésben részt vevő tagjának tanulmányi munkaidő-kedvezmény főszabály szerint jogszabály szerint nem jár, erre csak akkor jogosult, ha azt a szolgálati viszonyra vonatkozó szabály elrendeli vagy a tanulmányi szerződés megállapítja. Tanulmányi munkaidő-kedvezményként ebben az esetben a szolgálati viszonyra vonatkozó szabályban meghatározott vagy a tanulmányi szerződésben megállapított mértékű szabadidőt kell biztosítani. ${ }^{18}$

A hivatásos állomány tagja részére a tanulmányi munkaidő-kedvezmény tartamára távolléti díjat abban az esetben kell fizetni, ha a tanulmányok folytatására őt a rendvédelmi szerv - szolgálati viszonyra vonatkozó szabály alapján - kötelezte, vagy a távolléti díj fizetését tanulmányi szerződés állapítja meg. ${ }^{19}$

\section{Az illetmény és a tanulmányi szerződés}

A hivatásos állomány tagja havonta alapilletményre és az egyéb pótlékokra jogosult. Az alapilletmény beosztási illetményből, szolgálati időpótlékból és hivatásos pótlékból tevődik össze. Az ellátott feladattól és körülményektől függően a hivatásos állomány tagja a szolgálati törvényben megállapított egyéb pótlékokra jogosult. ${ }^{20}$

A képzésen való részvételnek, a tanulmányi szerződés megkötésének gyakran egyik indoka az, hogy a képzésben részt vevő olyan képesítést szerezzen meg, amellyel illetménynövekedést is elérhet - például pótlékra legyen jogosult. A hatályos szolgálati törvény idegennyelvtudási pótlékra vonatkozó rendelkezése hatással van a tanulmányi szerződéssel idegen nyelvi képzésben részt vevők kötelezettségeire.

Ha a rendvédelmi szerv tanulmányi szerződés alapján pénzügyi támogatást nyújt a nyelvvizsga megszerzéséhez - kivéve a felsőfokú szaknyelvi vizsgát -, a hivatásos állomány tagja az idegennyelvtudási pótlékra mindaddig nem jogosult, amíg a havonta fizetendő pótlék együttes összege nem éri el a tanulmányi szerződés alapján kifizetett pénzügyi támogatás mértékét. ${ }^{21}$

Ezen jogszabályi rendelkezés a rendvédelmi szerv anyagi érdekeinek védelme szempontjából ugyan érthető, de több szempontból is kifogásolható.

A szolgálati hely a támogatásért cserébe kétszeres biztosítékot vár el. Egyrészt a tanulmányi szerződésben foglalt ideig elvárja a szolgálati viszony fenntartását, másrészt a képzésre nyújtott támogatást visszaköveteli. A visszaköveteléssel a támogatást lényegében „kamatmentes kölcsönné” degradálja.

\footnotetext{
Hszt. 153. § (5) bek.

18 Hszt. 153. § (6) bek.

19 Hszt. 153 § (7) bek.

20 Hszt. 154. § (1) bek.

21 Hszt. 160. § (9) bek.
} 


\section{A megtérítési kötelezettség}

A képzésre vonatkozó megállapodások esetén a problémák akkor adódnak, ha valaki nem teljesíti a megállapodásban foglaltakat. Ennek oka lehet, hogy nem fejezi be a képzést, vagy a szolgálati viszonya megszűnik. Ezért a képzéshez nyújtott támogatások egyik legfontosabb kérdése az úgynevezett megtérítési kötelezettség.

A megtérítési kötelezettség nemcsak a tanulmányi szerződés esetén, hanem valamennyi képzési támogatásnál fennáll.

A megtérítés mértékét és módját azonban befolyásolja a tanulmányi szerződés megléte, és a jogszabályi elöírásokon túl szubjektív okok is, mint például a képzés elvégzését vállaló fél felróható magatartása, az állományilletékes parancsnok hozzáállása a méltányossági jogkörben gyakorolható jogosítványokhoz stb. Továbbá a megtérítés szempontjából az sem mindegy, hogy a szolgálati viszony a képzés alatt vagy utána szünik meg.

Általános elvként mondható ki azonban, hogy a képzést vállaló személy felróható magatartása a terhére eső körülményként értékelődik.

Így különösen akkor, ha a szolgálati viszony megszüntetésére fenyítés kiszabásával, vagy büntetőeljárás keretében szolgálati viszony megszüntetése, lefokozás, a szolgálati viszony keretében betöltött szolgálati beosztás ellátásához szükséges tevékenység folytatását kizáró foglalkozástól eltiltás vagy közügyektől eltiltás alkalmazásával kerül sor.

De ugyanígy abban az esetben is, ha a szolgálati viszony lemondással, más rendvédelmi szervhez történő áthelyezéssel szűnik meg. Valamint akkor is, ha törvény erejénél fogva szúnik meg a hivatásos állomány tagjának a szolgálati viszonya, mert a szolgálati viszony fenntartásához szükséges és az állományilletékes parancsnok által a hivatásos állomány tagjának előirt képzési és vizsgakötelezettség teljesítését önhibájából elmulasztotta, vagy az összeférhetetlenség megszüntetését elmulasztotta vagy a hivatásos szolgálatra alkalmatlanná vált, mert nem felel meg a kifogástalan életvitel követelményének. ${ }^{22}$

A megtérítési kötelezettség függ továbbá attól is, hogy az iskolarendszerú képzésben való részvétel esetén a szolgálati viszony mikor szünik meg: az oktatási intézmény által kötelezően előírt tanulmányi időnél rövidebb idő alatt vagy azt követően.

Ha az oktatási intézményben kötelező tanulmányi időnél rövidebb idő alatt - a fenti okokból - szünt meg a szolgálati viszony, akkor a rendvédelmi szerv a szolgálati beosztáshoz és előmenetelhez szükséges iskolarendszerú képzéshez térítésmentesen nyújtott támogatást időarányosan visszakövetelheti, ideértve a pénzbeli juttatásokat, a természetbeni élelmezés értékét, valamint a megállapított, de meg nem fizetett tandijnak azt a hányadát is, amelyet a felsőoktatási intézményben a szociális és tanulmányi kedvezményekkel is meg kellett volna fizetni. ${ }^{23}$

\footnotetext{
Hszt. 100. §.

Hszt. 100. § (1) bek.
} 
Tanulmányi szerződés esetén a szolgálati viszony fennállása (és fennmaradása) esetén a képzéshez nyújtott támogatás visszatérítése a polgári jogi szerződésszegés szabályai szerint alakulnak, a megtérítési kötelezettségre a felmondás, elállás rendelkezései az irányadók.

Ha azonban a hivatásos állomány tagjának szolgálati viszonya a Hszt. szerint megkötött tanulmányi szerződésben meghatározott időtartam („hűségidő”) előtt a felsorolt felróható okból szűnt meg, a hivatásos állomány tagja a tanulmányi szerződés alapján részére kifizetett tanulmányi támogatás összegét köteles

a) teljes mértékben megtéríteni, ha a szolgálati viszonya a tanulmányi szerződésben meghatározott időtartam megkezdése előtt szűnt meg,

b) időarányos mértékben megtéríteni, ha a szolgálati viszonya a tanulmányi szerződésben meghatározott időtartam megkezdése után, de annak letelte előtt szünt meg. ${ }^{24}$

A szolgálati viszony fennállta esetén a tanulmányi szerződés megszegéséből eredő megtérítési összeget az állományilletékes parancsnok azonban méltányosságból csökkentheti. ${ }^{25}$

A diszkrecionális munkáltatói jogkörből adódóan ez csak lehetőség, de nem kötelezettség. A döntés során az állományilletékes parancsnoknak egyedileg kell vizsgálnia a tanulmányi szerződésekből eredő visszatérítési kötelezettség mértékét.

A tanulmányi támogatás visszafizetésére kötelezés körében a méltányosság során az összehasonlítható helyzetben lévő személyek között az egyenlő bánásmód követelményét sértő különbségtétel azonban nem alkalmazható.

Az egyenlő bánásmód követelménye megtartásánál azonban nemcsak a tanulmányi szerződés megszegését kell vizsgálni, hanem a munkáltatói méltányossági jogkör gyakorlás - belső utasításon alapuló mindenkire alkalmazott - mérlegelési szempontjai is összehasonlítási alapot képeznek, mivel ez teremti meg az összehasonlítható helyzetet az egyenlő bánásmód követelményét sértő különbségtétel vizsgálatához. ${ }^{26}$

Előfordulhat tehát, hogy azonos képzésben részt vevő, a tanulmányi szerződést azonos módon megszegő személyekkel szemben a tanulmányi szerződés megszegése és felmondása esetén a méltányossági jogkör gyakorlása során eltérő döntés születik a visszatérítés kérdésében.

A diszkrimináció tilalma tehát nem azonos a mindenfajta megkülönböztetés tilalmával. Ahogy az Alkotmánybíróság rámutatott a megkülönböztetés arra is vonatkozik, hogy a jognak mindenkit egyenlő méltóságú személyként kell kezelnie, azaz azonos tisztelettel és körültekintéssel, az egyéni szempontok azonos mértékű figyelembevételével kell a jogosultságok és a kedvezmények elosztásának szempontjait meghatároz-

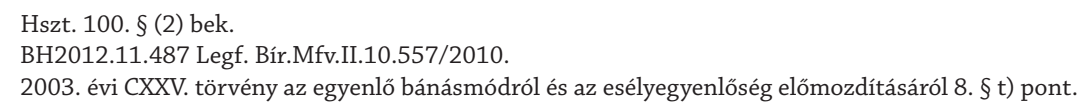


ni. ${ }^{27} \mathrm{~A}$ megkülönböztetés nem jogellenes, ha tárgyilagos mérlegelés szerint észszerü indoka van és nem önkényes. ${ }^{28}$

Így például a felsőfokú oktatás határidőre való be nem fejezése (például korábban a nyelvvizsga hiánya miatt) olyan szerződésszegés, amely a tanulmányi szerződésből eredő lényeges kötelezettségnek minősül, és mint ilyen felmondásra ad okot. A támogatás visszatérítése során azonban a szociális helyzet, egészségi állapot, egyéb méltányolható körülmények miatt eltérő összeg megállapítására kerülhet sor, annak ellenére, hogy a megtérítés alapját a tanulmányi szerződés azonos módon történő megszegése adja. ${ }^{29}$

Mindezek alapján látható, hogy az egyes képzési formák nemcsak jogi típusukat tekintve lehetnek eltérőek, hanem a jogok és kötelezettségek eltérése mellett a szerződésszegés esetén a következmények is eltérően alakulhatnak.

\section{Jogi források}

2003. évi CXXV. törvény az egyenlő bánásmódról és az esélyegyenlőség előmozdításáról (Ebtv.) 2012. évi I. törvény a Munka Törvénykönyvéről (Mt.)

2015. évi XLII. törvény a rendvédelmi feladatokat ellátó szervek hivatásos állományának szolgálati jogviszonyáról (Hszt.)

31/2015. (VI. 16.) BM rendelet a belügyminiszter irányítása alá tartozó rendvédelmi feladatokat ellátó szervek hivatásos állományát érintő személyügyi igazgatás rendjéről

9/1990. (IV. 25.) AB határozat

35/1994. (VI. 24.) AB határozat

BH2011.12.349. Legf. Bír.Mfv.II.10.557/2010.

BH2012.11.487 Legf. Bír.Mfv.II.10.557/2010.

\section{ABSTRACT}

\section{Education and Study Contracts at Law Enforcement Agencies}

Veronika HARGITAI

In present article the author introduces the education possibilities for law enforcement agencies. She presents the main types of education and the rights and obligations in connection with the specified education types. She points out the problems of the education and the consequences of not completing the education undertaken by the member of the law enforcement body.

Keywords: study contract, reimbursement, continuing education, working time reduction, education obligation 